\title{
Histopathology of Experimental Schistosoma bovis Infection in Goats
}

\author{
By R. Lindberg, J. Monrad, M. Vang Johansen, N.Ö. Christensen, and P. Nansen
}

Department of Pathology, Faculty of Veterinary Medicine, Swedish University of Agricultural Sciences, Uppsala, Sweden, Department of Veterinary Microbiology, Royal Veterinary and Agricultural University, Copenhagen, Denmark, and Danish Bilharziasis Laboratory, Charlottenlund, Denmark.

\begin{abstract}
Lindberg, R., J. Monrad, M. Vang Johansen, N. Ö. Christensen and P. Nansen: Histopathology of experimental Schistosoma bovis infection in goats. Acta vet. scand. 1993, 34, 183-191. - The inflammatory host response to Schistosoma bovis in young goats was studied at necropsy by light microscopy 34 weeks after primary exposure to 3,000 cercariae (group $B, n=6$ ), 34 weeks after primary exposure to 3,000 cercariae followed by challenge with 2,500 cercariae at week 17 (group $C, n=5$ ), and 17 weeks after primary exposure to 2,500 cercariae, given on week 17 of the experiment (group D, $\mathrm{n}=6$ ). Three goats served as uninfected controls. The faecal egg output had been minimal for 17 weeks prior to necropsy in groups B and C and only for the last 2 weeks in group D.

Histological studies were carried out on the small intestine, liver, lung and spleen, and tissue egg counts were performed. In sections of the small intestine and liver, a panel of histopathological variables were quantitated to characterize the host response and differences between groups of animals were evaluated with one way analysis of variance. The mean tissue egg count in the small intestine was slightly but not significantly higher in group $C$ than group B and about twice as high in group D (D vs B or C $\mathrm{p}<0.01$ ). Group means of numbers of inflammatory foci per section of gut wall corresponded well with those of tissue egg counts, suggesting that the rate of inflammatory destruction of eggs did not differ markedly between the groups. Egg material was less commonly seen in granulomas of the small intestine in group B than in group D $(p<0.01)$, suggesting lower passage of eggs through the gut wall during the later than during the earlier phase of patent primary infection. The frequency of eosinophil-rich hepatic inflammatory foci was much higher in group $D$ than in the other groups (D vs $\mathrm{B} p<0.05$, D vs $\mathrm{C} p<0.01$ ), and coincided with a high degree of blood eosinophilia in this group at the time of sacrifice. Challenged goats showed a significantly higher frequency of markedly fibrotic inflammatory foci in the liver and of liver granulomas with a marked giant cell component than goats of the other groups. Hepatic portal fibrosis was least prominent in animals with 17- week- old primary infections, implying a possible relation between this change and duration of infection.
\end{abstract}

\section{liver, intestine.}

\section{Introduction}

It has been repeatedly shown that in single high level Schistosoma (S.) bovis infection in goats and cattle, the faecal output of schistosome eggs reaches the lowest level within a few months post exposure, possibly as a result of acquisition of resistance with time (Saad et al. 1980, 1984, Kassuku et al. 1986, Monrad et al. 1991). Furthermore, primary infection has been shown to induce resistance to reinfection, expressed as a decrease in egg output and a reduced clinical response to challenge (Bushara et al. 1983b, Monrad et al. 1991). 
Although a decreased fecundity of adult female schistosomes has been claimed to be operative in reducing the egg output (Bushara et al. 1983a), the mechanisms of the host response are as yet largely unknown. The impact of the duration of infection upon the morphological host reactions also needs further study. The tissue reactions of the host to the worms and their ova in relation to the development of resistance are therefore of interest.

The present investigation was undertaken to study the morphology of the inflammatory response in goats with primary $S$. bovis infection of various durations and in goats challenged after a primary infection had become patent. Parasitological and clinico-pathological results from this study have been reported elsewhere (Monrad et al. 1991).

\section{Materials and methods}

Animals and experimental design

Twenty castrated West African Dwarf goats, 3 to 5 months old and weighing 10 to $14 \mathrm{~kg}$ at the beginning of the experiment, were used. The animals were kept indoors, pretreated with albendazole against gastrointestinal helminths and lung worms and fed on 2 to $3 \mathrm{~kg}$ of deer pellets $(63.5 \%$ grain, $17 \%$ oil seed cakes, $14 \%$ dried roughage, $5.5 \%$ supplement) per week and hay ad libitum.

The goats were allocated to 4 weight-matched groups, subjected to the following treatment:

- Group A: no $S$. bovis infection $(\mathrm{n}=3)$.

- Group B: primary infection week $0(n=6)$.

- Group C: primary infection week 0 and challenge infection week 17 $(\mathrm{n}=5)$.

- Group D: challenge control infection week $17(n=6)$.

This experimental set-up allowed a comparison between tissue responses in patent infec- tions of different durations and an assessment of the impact of challenge infection on host reactions. Cercariae of a bovine isolate of a Tanzanian S. bovis strain were produced in Bulinus truncatus snails and the goats were exposed to the cercariae percutaneously by leg immersion for $30 \mathrm{~min}$ (van Wyk et al. 1975). In order to prevent contamination of control animals, exposed goats were left in an isolated pen to dry for 2 to $3 \mathrm{~h}$ before they were mixed with uninfected goats. The animal exposure doses per animal were 3,000 cercariae for primary infection and 2,500 for challenge infection.

Animal weights, faecal egg counts and selected haematological and blood chemical variables were monitored every 2 weeks throughout the study. The procedures have been described in detail previously (Monrad et al. 1991). All animals were killed by shooting and bleeding on week 34 of the experiment and necropsies were performed.

\section{Histopathology and tissue egg counts}

Two pieces of the small intestine (1 approximately $4 \mathrm{~cm}$ long segment from the duodenum and midjejunum each at predetermined sites), 1 approximately $8 \mathrm{~cm}^{3}$ piece of the central area of the liver, and pieces of the lung and spleen were removed for microscopical examination. All tissues were fixed in 10 per cent neutral-buffered formalin. Three to 4 circumferential sections were cut from each intestinal specimen. Because of events beyond our control, adequate material from gut and spleen tissues was available from only 5 goats in group B and adequate liver and lung tissue from only 5 goats in group D. After paraffin embedding, $4 \mu \mathrm{m}$ thick sections were cut and stained with haematoxylin and eosin, Masson's trichrome and the combined Alcian blue (pH 3.0)-PAS technique.

Microscopical examination was performed by 
1 observer (R.L.) without prior knowledge of the identity of the animals. The tissue response was assessed in each goat as follows: Every circumscribed cellular inflammatory infiltrate (inflammatory focus) present in small intestinal and liver sections was counted and granulomatous infiltrates (granulomas) were specifically denoted. Spector's (1980) definition of the term granuloma was applied. The numbers of granulomas in the lungs were also noted. Inflammatory foci were characterized with regard to magnitude, cellular components and other features. The following variables were listed for inflammatory foci in the small intestine and liver: Degree of infiltration, graded + (few cells),++ (moderate numbers) and +++ (large numbers), of lymphoid cells and plasma cells in granulomas, degree of fibrosis (+ slight, ++ moderate, +++ marked) and presence of eosinophils (+ - +++ as for cells above) in inflammatory foci, and presence of Hoeppli reactions, eggshells and apparently intact eggs in inflammatory foci. The presence of eggs and eggshells devoid of an inflammatory reaction was noted in the gut sections. Granulomas in which the mononuclear phagocyte population was markedly dominated by giant cells (GC granulomas) or macrophages and epithelioidlike cells (EC granulomas) were listed. Presence of lymphoid follicles as well as disintegrating worms in inflammatory foci were specifically noted for liver sections.

In each goat and organ, the numbers of granulomas with marked lymphoid cell and plasma cell components (grades++ and +++) and the numbers of EC and GC granulomas were expressed in relation to the total number of granulomas found (percentage of total numbers of granulomas). Inflammatory foci with marked fibrosis $(+++)$, marked eosinophil infiltration (++ and +++ ), presence of Hoeppli reactions, eggshells and intact eggs were ex- pressed likewise in relation to the total number of inflammatory foci found. The presence of egg material devoid of any inflammatory change were also related to the total number of inflammatory foci. The numbers of inflammatory foci per circumferential section of the intestine and the relations of numbers of granulomas and eggs in the mucosa to those in deeper layers of gut sections were determined.

Non-focal inflammatory changes in the gut and liver were assessed, and in the liver the degrees of portal fibrosis, scattered plasmacellular, eosinophil and lymphoid cell infiltration, globule leucocyte infiltration and liver cell necrosis were subjectively scored 0 (no or minimal change), 0.5 (slight change), 1 (moderate change) or 1.5 (heavy change). Findings in lung and spleen sections were assessed as described in the Results section.

Tissue counts of schistosome eggs were determined after potassium hydroxide digestion as described by Kassuku et al. (1986) in the liver and in 2 segments of the small intestine approaching the sites selected for histopathological examination .

\section{Statistical method}

Histopathological data and tissue egg counts in groups B, C and D were analysed using a statistical computer program (SAS 1982) in a one-way analysis of variance (ANOVA) with subsequent paired comparisons of means; differences were considered statistically significant at $\mathrm{p}<0.05$.

\section{Results}

\section{Faecal egg counts}

In groups $\mathrm{B}$ and $\mathrm{C}$, the maximal egg excretion occurred between the 8 th and 12 th weeks after the primary infection, decreasing rapidly to reach the lowest level at week 16, i.e. the challenge infection did not induce any addi- 
Table 1. Mean tissue egg counts (eggs per gram tissue) in the small intestine in the various groups. Group B: primary, non-challenged; Group C: primary, challenged; Group D: challenge control. Statistical data evaluated with one way ANOVA.

\begin{tabular}{lcc}
\hline Group & Egg count & No. of goats \\
\hline B & 1176 & 6 \\
C & 1300 & 5 \\
D & 2651 & 6 \\
\hline
\end{tabular}

B vs $\mathrm{D}: \mathrm{p}<0.01$.

C vs $\mathrm{D}: \mathrm{p}<0.01$.

tional egg excretion. The egg excretion pattern in group D was similar, though the maximal egg count was lower (see Monrad et al. 1991).

\section{Clinical pathology}

High egg excretion was accompanied by marked anaemia, blood eosinophilia, hypoalbuminaemia and poor weight gain (see Monrad et al. 1991). These changes gradually diminished with decreasing egg output from week 14 after the primary infection. The challenge infection did not induce any further changes in these variables.

\section{Tissue egg counts}

The mean tissue counts of schistosome eggs at the 2 sites in the small intestine in the animals of groups B, C and D are shown in Table 1 . Group D showed a significantly higher egg count at these sites than the other groups. The difference between groups $\mathrm{B}$ and $\mathrm{C}$ was not statistically significant.

\section{Histopathology}

Small intestine. No lesions of significance were encountered in the group A goats.

Pertinent numerical data concerning the infected groups are given in Table 2. The numbers of eggs and eggshells per section of intes- tine were significantly higher in group $D$ than in group $B(p<0.05)$. Likewise, the proportion of inflammatory foci with eggshell structures present was higher in group $D$ than in group $B$ $(\mathrm{p}<0.01)$.

No significant differences were found between the infected groups in respect to the other variables listed. However, the differences between groups $\mathrm{B}$ and $\mathrm{C}$ approached significance regarding the proportion of GC granulomas, which tended to be higher in group C. Prominence of lymphoid cells in granulomas was in general an uncommon fea-

Table 2. Total numbers of inflammatory foci examined and selected pertinent histopathological features in sections of the small intestine. Group B: primary, non-challenged; Group C: primary, challenged; Group D: challenge control. Group means presented unless stated otherwise. Statistical data evaluated with one way ANOVA.

\begin{tabular}{|c|c|c|c|c|}
\hline & \multicolumn{3}{|c|}{ Group } & \multirow[b]{2}{*}{ Statistics } \\
\hline & B & $\mathrm{C}$ & $\mathrm{D}$ & \\
\hline Goats (n) & 5 & 5 & 6 & \\
\hline $\begin{array}{l}\text { Inflammatory } \\
\text { foci available } \\
\text { per group (n) }\end{array}$ & 89 & 137 & 268 & \\
\hline $\begin{array}{l}\text { Inflammatory } \\
\text { foci per section } \\
\text { of intestine (n) }\end{array}$ & 5.6 & 6.8 & 11.5 & N.S. \\
\hline $\begin{array}{l}\text { Eggs and eggshe } \\
\text { per section of } \\
\text { intestine }(n)\end{array}$ & 2.9 & 4.4 & 8.6 & B vs D $p<0.05$ \\
\hline $\begin{array}{l}\text { GC granulomas } \\
(\%)^{\mathrm{a}}\end{array}$ & 2.8 & 14.7 & 8.0 & N.S. \\
\hline $\begin{array}{l}\text { Inflammatory fo } \\
\text { with eggshells } \\
(\%)^{\mathrm{b}}\end{array}$ & 34.0 & 49.2 & 63.0 & B vs D $p<0.01$ \\
\hline
\end{tabular}

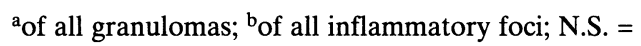
no significant differences found; $n=$ number. 
ture. The number of inflammatory foci per section of intestine increased with group order B to D, although the differences failed to reach statistical significance. The relation between tissue egg count and number of inflammatory foci per section of intestine was roughly similar in all groups (compare Tables 1 and 2). The proportion of granulomas out of all inflammatory foci was high and approximately similar in all groups (means of groups ranging from 79.6 to 95.2 per cent).

The proportion of foci showing a Hoeppli reaction varied between 9.4 and 17.1 per cent and foci with marked eosinophilia accounted for 25.5 to 38.9 per cent of all foci in the various groups. Lymphoid hyperplasia, tissue eosinophilia and plasmacytosis beyond distinct inflammatory foci were consistent features of the gut histology in all groups, and globule leucocytes appeared more common in the mucosa of infected than of non-infected goats.

Liver. No lesions of significance were present in the group A goats. Globule leucocytes were not found in the bile duct epithelium of the liver in those animals. In all infected groups (Table 3), lymphoid cell infiltration and plasmacytosis of inflammatory foci appeared much more prominent in the liver than in the intestine. The proportion of foci with marked eosinophilia was higher in group $\mathrm{D}$ than in the other groups (D vs $\mathrm{B}$ $\mathrm{p}<0.05$, D vs $\mathrm{C} p<0.01)$. GC granulomas and markedly fibrotic focal reactions were significantly most prevalent in group $\mathrm{C}$. The score of portal fibrosis was higher in groups $\mathrm{B}$ and $\mathrm{C}$ than in group $\mathrm{D}$ ( $\mathrm{B}$ vs $\mathrm{D} \mathrm{p}<0.05, \mathrm{C}$ vs $\mathrm{D}$ $\mathrm{p}<0.01)$ and the score of scattered plasmacytosis was higher in group $\mathrm{C}$ than group $\mathrm{B}$ $(\mathrm{p}<0.05)$.

The other variables tested showed no significant differences between the infected groups. However, the difference between groups $\mathrm{C}$ and $\mathrm{D}$ regarding the proportion of EC granulomas approached significance, with a tendency towards a higher frequency in group $\mathrm{D}$. Lymphoid follicles accounted for 26.8 to 34.0 per cent of all inflammatory foci and Hoeppli reactions were observed only in 1.4 per cent or less of all foci in each group. Moderate numbers of globule leucocytes were found in the bile duct epithelium of all infected groups.

Table 3. Total numbers of inflammatory foci examined and selected pertinent features of the histopathology in liver sections. Group B: primary, nonchallenged; Group C: primary, challenged; Group D: challenge control. Group means presented unless stated otherwise.Statistical data evaluated with one way ANOVA.

\begin{tabular}{|c|c|c|c|c|}
\hline & \multicolumn{3}{|c|}{ Group } & \multirow[b]{2}{*}{ Statistics } \\
\hline & B & $\mathrm{C}$ & D & \\
\hline Goats (n) & 6 & 5 & 5 & \\
\hline $\begin{array}{l}\text { Inflammatory } \\
\text { foci available } \\
\text { per group (n) }\end{array}$ & 100 & 136 & 189 & \\
\hline $\begin{array}{l}\text { GC granulomas } \\
(\%)^{\mathrm{a}}\end{array}$ & 28.0 & 54.0 & 26.0 & $\begin{array}{l}\text { B vs } C p<0.05 \\
C \text { vs } D p<0.01\end{array}$ \\
\hline $\begin{array}{l}\text { EC granulomas } \\
(\%)^{\mathrm{a}}\end{array}$ & 60.5 & 38.8 & 74.6 & N.S. \\
\hline $\begin{array}{l}\text { Foci with } \\
\text { eosinophilia } \\
(\%)^{b}\end{array}$ & 31.5 & 27.2 & 65.4 & $\begin{array}{l}\text { B vs D } p<0.05 \\
\text { C vs D } p<0.01\end{array}$ \\
\hline $\begin{array}{l}\text { Fibrotic foci } \\
(\%)^{b}\end{array}$ & 1.0 & 15.4 & 6.0 & $\begin{array}{l}\text { B vs } C p<0.001 \\
\text { C vs } D p<0.05\end{array}$ \\
\hline $\begin{array}{l}\text { Plasmacytosis } \\
\text { score }\end{array}$ & 0.5 & 1.4 & 1.1 & B vs $\mathrm{C} p<0.05$ \\
\hline $\begin{array}{l}\text { Portal fibrosis } \\
\text { score }\end{array}$ & 1.0 & 1.2 & 0.6 & $\begin{array}{l}\text { B vs D } p<0.05 \\
C \text { vs D } p<0.01\end{array}$ \\
\hline
\end{tabular}

${ }^{a}$ of all granulomas; ${ }^{b}$ of all inflammatory foci; N.S. = no significant differences found; $n=$ number. 
Spleen. No abnormalities were seen in the goats of group A. In all infected animals, the spleen displayed evidence of chronic inflammatory changes. The splenic corpuscles were moderately to markedly hyperplastic and there was moderate to marked plasma cell infiltration of the red pulp.

Lungs. The alveolar parenchyma of the lungs showed slight diffuse hyperplasia of the epithelial lining in all goats. Alveolar epithelial hyperplasia and alveolar macrophage infiltration were more marked in infected than in non-infected goats, but the occurrence of lymphoid nodules was essentially similar. Granulomas with epithelioid-like cells and giant cells were observed in some of the goats in groups B ( 2 of 6 ) and C ( 3 of 5), but none were found in group D. Scattered granulomatous alveolitis with microclusters of epithelioid cells was noted in 1 goat of each infected group.

\section{Discussion}

The goats of the present study showed an effective regulatory response to primary infection with $S$. bovis and strongly resisted a challenge exposure (Monrad et al. 1991). Thus, at the end of the experiment, groups B and C had displayed minimal faecal egg output for 17 - 18 weeks, whereas in the challenge control animals the egg excretion had peaked only 8 weeks before and abated to a low level during the last 2 weeks only. In the latter group, the infection was clinically manifest and there was pronounced blood eosinophilia and anaemia at the end of the study (Monrad et al. 1991). Tissue egg counts (Monrad et al. 1991 ; present study) showed that despite reexposure, the egg density in the challenged group was only slightly above that in group B, whereas the count in the challenge controls was markedly higher, particularly in the small intestine and liver.

The mechanisms underlying the regulation of faecal egg output and resistance to challenge infection with $S$. bovis have not been investigated in goats. In cattle, studies indicate that decreased fecundity of adult worms is a major factor in both $S$. bovis and $S$. mattheii infections and that reduction of the worm populations may also contribute, at least with $S$. bovis (Lawrence 1977a, Bushara et al. 1980, Saad et al. 1980). Retention of eggs in the tissues has also been discussed as a contributory factor in lowering the egg output in S. bovis infection of cattle (Saad et al. 1980). The importance of 'concominant immunity' (Smithers \& Terry 1965) seems unclear in ruminant schistosomiasis, and other possible mechanisms, such as increased egg destruction and inhibition of maturation of eggs in tissues (Olds \& Mahmoud 1980, Garcia et al. 1983) have apparently not been investigated in ruminants. The present study was performed retrospectively on the goat material from the study of Monrad et al. (1991). We were primarily interested in seeing whether the challenge infection would induce any appreciable changes in the pattern of tissue reactions, especially in the liver and intestine, that might have a bearing on the sustained depression of egg output following challenge. We also wished to compare the host reactions in single primary infections of different durations. Using the designed approach with quantification of selected histopathological variables followed by statistical evaluation, some features of interest were found to differ between the studied groups. In addition, some variables showed inter-group differences approaching statistical significance and it therefore seemed that more rewarding results could have been expected if the number of goats investigated had been somewhat larger. The histological 
material from the intestine was probably satisfactorily representative, since, as seen by comparing Tables 1 and 2, the numbers of eggs and eggshells per tissue section corresponded fairly well to the egg counts in the small bowel tissue in the various groups. The tissue egg count in the small intestine was significantly higher in the group carrying a 17 week -old single infection than in the others $(p<0.01)$. This group also showed the highest frequency of intestinal inflammatory foci containing eggshells, and the difference in this respect from the group with the 34- week- old infection was significant $(\mathrm{p}<0.01)$.The numbers of inflammatory foci, including granulomas, per section of gut did not differ significantly between the groups. On the other hand, the mean number of inflammatory foci was proportional to the tissue egg count in the individual groups. Thus we found it unlikely that a gradual build-up of inflammatory foci in the process of egg destruction in the gut wall during the course of infection would have had any substantial bearing upon the decrease of egg excretion with increasing duration of a single infection or upon challenge. The numbers of eggs and egg residues per bowel section were significantly smaller after 34 weeks than after 17 weeks of single infection $(p<0.05)$. In the light of the above observations, this could imply an effect of a lower recent passage of eggs into the gut wall at 34 than at 17 weeks. As pointed out by Lawrence (1980), it is possible that the eggs of the intestinal granulomas were absorbed to a higher degree at the more chronic stage than after a shorter duration of infection.

In the liver, the group with a 17- week- old single infection showed a markedly higher proportion of inflammatory foci with a pronounced component of eosinophils than the other groups. No marked differences were observed between groups regarding eosinophil infiltration in other tissues examined. When these animals were killed, they showed a high second peak of blood eosinophilia (Monrad et al. 1991). Although we cannot draw any conclusions as to the cause of this eosinophil peak, a causal relationship between the tissue eosinophilia in the liver and the blood eosinophilia is a possibility. The degree of non-focal liver fibrosis appeared to be lowest in the challenge control group, thus suggesting that diffuse portal hepatic fibrosis may be related to the duration of infection. The challenged group showed the highest frequency of greatly fibrotic hepatic inflammatory foci. The reasons for this change are far from clear, but the possibility should be explored as to whether, with reinfection, relatively more worms might be translocated to the liver from their habitat in the mesenteric veins and subsequently destroyed, with resultant fibrotic tissue repair. The cause and biological significance of the preponderance of markedly giant cellular responses of granulomatous foci in the liver of the challenged group also merits further study, especially since there was a similar tendency, though not significant, in the small intestine of that group. We did not actually measure the size of the granulomas, but markedly giant-cellular foci were of varying magnitudes and we found no evidence that in general they resembled the involution stage giant cell reaction previously described in schistosomiasis (von Lichtenberg et al. 1973).

In bovine schistosomiasis, Lawrence (1977b) found that globule leucocytes were most widely distributed and most numerous in animals subjected to repeated heavy infection. In the present study, globule leucocytes of the bile duct epithelium were only found in infected goats, and their numbers in the small intestinal mucosa also appeared to increase with infection. However, we found no substantial increase in this cell population in the 
liver or small intestine in relation to reinfection or to an increased duration of patent infection. The observed splenic follicular hyperplasia and plasmacytosis are in accordance with results of earlier studies on $S$. bovis in goats (Saad et al. 1984), and suggest a pronounced B cell response to infection. There was no evidence of any substantial lymphoid hyperplasia in the lungs due to infection, in contrast to previous observations in $S$. bovis and $S$. mattheei infections in calves (Hussein 1971). Pulmonary granulomas were only seen in groups $\mathrm{B}$ and $\mathrm{C}$. Their cause was not established, but pulmonary egg deposition, possibly secondary to establishment of an open porto-systemic collateral circulation, seems most likely.

The present morphological analysis has provided some data concerning the impact of duration of infection and of challenge exposure on the tissue response in caprine $S$. bovis infection. It is clear, however, that further studies are needed to obtain a better understanding of the basic features in the dynamics of the inflammatory response. Such studies should preferably include animals killed at shorter intervals throughout prepatent and patent stages of infection and should involve vessel perfusions to provide quantitative and qualitative data on the worm population. Furthermore, the present results suggest that in order to explain the observed decrease in faecal egg output, more studies should be devoted to mechanisms governing the establishment and fecundity of schistosomes.

\section{Acknowledgements}

We wish to thank Dr Birgitta Vegerfors and Dr Curt Rönnbäck for help and comments on statistical analysis. This study was supported by SAREC, Sweden (grant no. 5.11 SWE-91-114) and the Danish Research Council for Development Research (grant no. 104 DAN 8/832).

\section{References}

Bushara HO, Majid AA, Saad AM, Hussein MF, Taylor MG, Dargie JD, Marshall TF de C, Nelson $G S$ : Observations on cattle schistosomiasis in the Sudan, a study in comparative medicine. II. Experimental demonstration of naturally acquired resistance to Schistosoma bovis. Amer.J.trop. Med. Hyg. 1980, 29, 442-451.

Bushara HO, Hussein MF, Majid MA, Musa BEH, Taylor MG: Observations on cattle schistosomiasis in the Sudan, a study in comparative medicine. IV. Preliminary observations on the mechanism of naturally acquired resistance. Amer. J.trop. Med. Hyg. 1983a, 32, 1065-1070.

Bushara HO, Gameel AA, Majid BYA, Khitma I, Haroun EM, Karib EA, Hussein MF, Taylor MG: Observations on cattle schistosomiasis in the Sudan, a study in comparative medicine. VI. Demonstration of resistance to Schistosoma bovis challenge after a single exposure to normal cercariae or to transplanted adult worms. Amer. J. trop. Med. Hyg. 1983 b, 32, 1375-1380.

Garcia EG, Mitchell GF, Tapales FP, Tiu WU: Reduced embryonation of Schistosoma japonicum eggs as a contributory mechanism in modulation of granuloma in chronically sensitized mice. Southeast Asian J. trop. Med. Public Health 1983, 14, 272-273.

Hussein MF: The pathology of experimental schistosomiasis in calves. Res .vet .Sci. 1971, 12, 246252.

Kassuku AA, Christensen NÖ, Nansen P, Monrad J: Clinical pathology of Schistosoma bovis infection in goats. Res .vet .Sci. 1986, 40, 44-47.

Lawrence JA: Schistosoma mattheei in the ox: Observations on the parasite. Vet. Parasitol. 1977a, 3, 291-303.

Lawrence JA: The globule leucocyte in bovine schistosomiasis. Res. vet. Sci. 1977b, 23, 239-240.

Lawrence JA: The pathogenesis of Schistosoma mattheei in the sheep. Res. vet. Sci. 1980, 29, 1-7.

Lichtenberg F von, Erickson DG, Sadun EH: Comparative histopathology of schistosome granulomas in the hamster. Amer.J.Pathol. 1973, 72, 149177.

Monrad J, Christensen NÖ, Nansen P: Acquired resistance in goats following a single primary Schistosoma bovis infection. Acta Trop. 1991, 48, 6977.

Olds GR, Mahmoud AAF: Role of host granulomatous response in murine schistosomiasis mansoni - eosinophil mediated destruction of egg. J. clin. 
Invest. 1980, 66, 1191-1199.

Saad AM, Hussein MF, Dargie JD, Taylor MG, Nelson GS: Schistosoma bovis in calves: the development and clinical pathology of primary infections. Res. vet .Sci. 1980, 28, 105-111.

Saad AM, Hussein MF, Dargie JD, Taylor MG: The pathogenesis of experimental Schistosoma bovis infections in Sudanese sheep and goats. J .Comp. Pathol. 1984, 94, 371-384.

SAS Institute Inc.: SAS User's Guide: Statistics. SAS Institute Inc., Cary, NC, USA, 1982.

Smithers $S R$, Terry RJ: Naturally acquired resistance to experimental infections of Schistosoma mansoni in the rhesus monkey (Macaca mulatta). Parasitology 1965, 55, 701-710.

Spector WG: The morphology, kinetics and fate of granulomas. Verh. dtsch. Ges. Pathol. 1980, 64, 21-24.

van Wyk JA, Heitmann LP, van Rensburg LJ: Studies on schistosomiasis. 7. A comparison of various methods for the infestation of sheep with Schistosoma mattheei. Onderstepoort J.vet.Res. 1975, 42, 71-74.

\section{Sammanfattning \\ Histopatologin vid experimentell Schistosoma bovis infektion hos get.}

Det inflammatoriska värddjurssvaret mot Schistosoma bovis hos unga getter undersöktes ljusmikroskopiskt 34 veckor efter primär exponering för 3.000 cerkarier (grupp B, $n=6$ ), 34 veckor efter primär exponering för 3.000 cerkarier följd av challengeexponering för 2.500 cerkarier vecka 17 (grupp $C, n=5$ ), samt 17 veckor efter primär exponering för 2.500 cerkarier, utförd under 17:e försöksveckan (grupp
$\mathrm{D}, \mathrm{n}=6)$. Tre getter var icke exponerade kontroller. Äggutskiljningen i träcken hade varit minimal under 17 veckor före obduktion i grupperna $B$ och $C$ och endast under de sista 2 veckorna i grupp D.

Histopatologiska undersökningar utfördes på material från tunntarm, lever, lunga och mjälte. Antalet ägg i olika vävnader (ägg per gram vävnad) beräknades. I vävnadssnitt från tunntarm och lever kvantifierades en rad morfologiska variabler för att karakterisera värddjurssvaret. Skillnader mellan de olika djurgrupperna analyserades statistiskt med envägs variansanalys. Antalet ägg per gram tunntarmsvävnad var något, men ej signifikant, högre i grupp C än i grupp B och betydligt högre i grupp D (D vs B eller $\mathrm{C} p<0.01$ ). Gruppmedelvärden för antalet inflammatoriska härdar per vävnadssnitt av tunntarmen visade god överenstämmelse med antalet ägg per gram vävnad, antydande att graden av inflammatorisk destruktion av ägg i tunntarmen var likartad i de olika grupperna. Äggstrukturer sågs mera sällan i tunntarmsgranulom hos grupp B än hos grupp $D(p<0.01)$, antydande lägre grad av passage av ägg genom tarmväggen under senare än under tidigare fas av patent primärinfektion. Frekvensen av inflammatoriska härdar med markant eosinofili i levern var mycket högre i grupp $D$ än i de andra grupperna ( $\mathrm{D}$ vs $\mathrm{B} \mathrm{p}<0.05$, D vs $\mathrm{C} p<0.01$ ), tidsmässigt korrelerat till kraftig blodeosinofili hos grupp D getter. Den grupp som utsatts för challengeexponering visade signifikant högre frekvens av markant fibrotiska inflammatoriska härdar och av uttalat jättecelliga granulom i levern än andra grupper. Portal leverfibros var minst uttalad hos djur med 17 veckor gammal primärinfektion, talande för en effekt av infektionens duration för graden av denna förändring.

(Received December 22, 1992; accepted January 14, 1993).

Reprints may be requested from: R. Lindberg, Department of Pathology, P.O. Box 7028, S-750 07 Uppsala, Sweden. 